THE effects of different sensitization and allergen provo cation regimens on the development of allergen-induced bronchial hyperreactivity (BHR) to histamine were investigated in conscious, unrestrained guinea-pigs. Similar early and late phase asthmatic reactions, BHR for inhaled histamine after the early $(6 \mathrm{~h})$ as well as after the late reaction $(24 \mathrm{~h})$, and airway inflammation were observed after a single allergen provocation in animals sensitized to produce mainly IgG or IgE antibodies, respectively. Repeating the allergen provocation in the IgE-sensitized animals after 7 days, using identical provocation conditions, resulted in a similar development of BHR to histamine inhalation. Repetition of the allergen provocation during 4 subsequent days resulted in a decreased development of BHR after each provocation, despite a significant increase in the allergen provocation dose necessary to obtain similar airway obstruction. The number of inflammatory cells in the bronchoalveolar lavage was not significantly changed after repeated provocation, when compared with a single allergen provocation. Finally, we investigated allergen-induced bronchial hyperreactivity by repetition of the sensitization procedure at day 7 and 14 (booster), followed by repeated allergen provocation twice a week for 5 weeks. Surprisingly, no BHR to histamine could be observed after either provocation, while the number of inflammatory cells in the bronchoalveolar lavage fluid after 5 weeks was enhanced compared with controls. These data indicate that both IgE and IgG sensitized guinea-pigs may develop bronchial hyperreactivity after a single allergen provocation. Repeated allergen exposure of IgE sensitized animals causes a gradual fading of the induced hyperreactivity despite the on-going presence of inflammatory cells in the airways, indicating a mechanism of reduced cellular activation.

Key words: Allergic asthma, Bronchial hyperreactivity, Guinea-pigs, IgE, IgG, Inflammation, Sensitization

\section{Influence of sensitization and allergen provocation procedures on the development of allergen- induced bronchial hyperreactivity in conscious, unrestrained guinea- pigs}

\author{
R. E. Santing, ${ }^{\text {CA }}$ C. G. Olymulder, \\ B. van Diepen, H. Meurs and J. Zaagsma
}

Groningen/Utrecht Institute for Drug Exploration, Department of Medicinal Chemistry and Molecular Pharmacology, University of Groningen, A. Deusinglaan 2, 9713 AW Groningen, the Netherlands

CA Corresponding Author

\section{Introduction}

Allergen-induced early (EAR) and late (LAR) phase asthmatic reactions, bronchial hyperreactivity (BHR), and airway inflammation are common characteristics of allergic asthma. Bronchial reactivity increases upon exposure to airborne allergens and appears to be related to the development of a LAR, since enhanced reactivity to inhaled histamine and methacholine was observed in asthmatic patients responding to allergen provocation with an EAR as well as a LAR (dual responders), while no increase was found in patients who developed an EAR only. ${ }^{1-3}$ It was also observed that bronchial reactivity was already increased before the LAR was clinically manifest, suggesting that this early developed BHR may contribute to the severity of the LAR. ${ }^{3}$ The development of the LAR and the allergen-induced increase in bronchial reactivity are associated with an influx of inflammatory cells into the airways, ${ }^{4,5}$ indicating that airway inflammation may be involved in these processes.

The class and concentration of circulating reaginic antibodies may determine to a large extent the development of clinical symptoms of allergic asthma. Cutaneous late phase reactions are IgE-dependent and can be transferred passively; the ability to perform these passive transfers is eliminated by removal of the IgE antibodies from the serum and restored by administration of the IgE fraction. ${ }^{6,7}$ Evidence that LARs are also IgE-dependent comes from the observation that they can be produced by inhalation of anti-IgE antibodies. ${ }^{8}$

Experimentally induced IgE and IgG reaginic antibody formation in guinea-pigs greatly depends on the sensitization and allergen provocation procedures applied. ${ }^{9,10}$ Addition of $\mathrm{Al}(\mathrm{OH})_{3}$ to the sensitization solution facilitates the production of IgE antibodies after parental administration of this solu- 
tion, whereas in the absence of adjuvant or in the presence of Freund's Complete Adjuvant mainly IgG antibodies are produced. ${ }^{9,10}$ Tracheal instillation of an immobilized allergen (ovalbumin coupled to Sepharose) caused a dual asthmatic reaction in guinea-pigs sensitized to IgE, whereas in guinea-pigs sensitized to IgG, only an EAR was observed. ${ }^{11}$ The influence of IgE and IgG sensitization procedures on the development of early and late asthmatic reactions, BHR and airway inflammation after inhalational challenge with aerosolized allergen is, however, unclear.

Therefore, using a new model of chronically instrumented, conscious and unrestrained guineapigs,${ }^{12}$ we investigated these responses in two groups of guinea-pigs that were sensitized to produce mainly IgG or IgE antibodies to ovalbumin, respectively.

Similar to the allergic responses in human asthmatics, we have shown recently that the IgE-sensitized guinea-pigs develop dual asthmatic reactions as well as BHR to histamine and airway inflammation after these reactions following a single allergen challenge with ovalbumin aerosol. ${ }^{13}$ The effects of more prolonged, repeated exposures to allergen on airway reactivity in this model are still unclear. Such exposures could lead to enhancement of inflammatory responses in the airways and therefore to a greater degree of BHR than that observed after a single exposure. Since chronic natural inhalational exposure of asthmatic patients to allergen may indeed be relevant to the development of BHR in these patients, ${ }^{14}$ we subsequently tried to enhance allergeninduced development of BHR to inhaled histamine by increasing the frequency of allergen provocations. In a final protocol, we tried to optimize the possible development of BHR by repeating the sensitization procedure (booster) in combination with a further increase in the number of allergen provocations.

\section{Methods}

Sensitization and challenge procedures: Specific pathogen-free guinea-pigs (Charles River SAVO, Kiszlegg, Germany), weighing approximately 300 g, were used in this study. The animals were housed in individual cages in climate-controlled animal quarters and given water and food ad libitum.

For the first part of this study, the animals were divided into three separate groups. The first group (control) was not sensitized. The second group (IgG) was sensitized with an emulsion of equal volumes of saline and Freund's Complete Adjuvant, containing $100 \mu \mathrm{g} / \mathrm{ml}$ ovalbumin. The third group (IgE) was sensitized with a suspension of $100 \mathrm{mg} / \mathrm{ml} \mathrm{Al}(\mathrm{OH})_{3}$ in $100 \mu \mathrm{g} / \mathrm{ml}$ ovalbumin in saline.

The antigen solution $(0.5 \mathrm{ml})$ was injected i.p. and another $0.5 \mathrm{ml}$ was divided over seven s.c. injection sites in the proximity of lymph nodes in the paws, lumbar regions and neck. These procedures facilitate selective production of IgG and IgE antibodies, respectively, as determined by passive cutaneous anaphylaxis. ${ }^{10}$ The animals were challenged by aerosol 4-5 weeks after sensitization with either saline (control) or increasing concentrations of ovalbumin $(1,3,5,7,10,20 \mathrm{mg} / \mathrm{ml})$ for $3 \mathrm{~min}$ with $10 \mathrm{~min}$ intervals, until signs of respiratory distress were observed.

In the second part of this study only the IgEsensitization procedure described above was used. The sensitized animals were challenged with ovalbumin aerosol as described above either once (IgE), twice $(\operatorname{IgE}-2 \times)$ or four times $(\operatorname{IgE}-4 \times)$. The interval between subsequent allergen provocations was 7 days (IgE-2x) or $24 \mathrm{~h}(\operatorname{IgE}-4 \times)$. In a final group (IgE-10x), the IgE sensitization described above was repeated at day 7 and 14 (boostering). These animals were challenged with allergen twice a week for 5 weeks, starting 14 days after the last sensitization.

All protocols were approved by the University of Groningen Animal Health Committee, which is responsible for the care and proper use of experimental animals.

Measurement of airway function: Airway function was assessed by $\mathrm{P}_{\mathrm{pl}}$ measurement as described previously. ${ }^{12}$ In brief, a small latex balloon, connected to a saline-filled tube, was surgically implanted inside the thoracic cavity. The cannula was driven subcutaneously and permanently attached to the neck of the animal. After connection via another fluid-filled cannula to a pressure transducer (Gould P23ID, Gould Medical BV, Bilthoven, The Netherlands), $\mathrm{P}_{\mathrm{pl}}$ was measured using an on-line computer system. No post-surgical inflammation was observed for at least 5 weeks after operation and baseline $\mathrm{P}_{\mathrm{pl}}$ values remained stable during repeated measurements on different days. ${ }^{12}$ Using a combination of flow measurement with a pneumotachograph, implanted inside the trachea, and pressure measurement with the pleural balloon, we showed that changes in $\mathrm{P}_{\mathrm{pl}}$ are linearly related to changes in airway resistance and hence can be used as a sensitive index for histamineand allergen-induced bronchoconstriction. ${ }^{12}$

Provocation procedures: For aerosol provocation, an animal cage was developed in which the guinea-pigs could move freely. ${ }^{12}$ The volume of the cage was 91 , which ensured a fast replacement of the air inside the cage with aerosol and vice versa. A De Vilbiss nebulizer (type 646, De Vilbiss, Somerset, PA, USA) driven by an airflow of $8 \mathrm{l} / \mathrm{min}$, provided the aerosol required, with an output of $0.43 \mathrm{ml} / \mathrm{min}$.

The animals were habituated to the experimental conditions on 2 separate days. Subsequently, animals were challenged with saline, histamine and 
ovalbumin aerosols. All provocations were preceded by an additional adaptation period of at least $30 \mathrm{~min}$, followed by two consecutive control challenges with saline.

Histamine provocations were performed with a 25 $\mu \mathrm{g} / \mathrm{ml}$ solution of histamine in saline, followed by increasing dosage steps of $25 \mu \mathrm{g} / \mathrm{ml}$. Each provocation lasted $3 \mathrm{~min}$ and was separated by $10 \mathrm{~min}$ intervals. Animals were challenged until the $\mathrm{P}_{\mathrm{pl}}$ increased by more than $100 \%$ for at least 3 consecutive min. The provocation concentration causing a $100 \%$ increase in $\mathrm{P}_{\mathrm{pl}}\left(\mathrm{PC}_{100}\right)$ was derived by linear interpolation.

Experimental protocol: To establish baseline histamine $\mathrm{PC}_{100}$-values, two provocation sessions were performed, separated by 3 days. Variations between the first and second $\mathrm{PC}_{100}$-values were small $(3.8 \pm 2.6 \%, n=31)$.

One day after the second histamine provocation allergen provocations were performed. At $6 \mathrm{~h}$ (between the EAR and LAR) and $24 \mathrm{~h}$ (after the LAR) following allergen exposure to IgG and IgE sensitized guinea-pigs, histamine $\mathrm{PC}_{100}$-values were reestablished to assess changes in airway reactivity at these time points. The second prechallenge histamine $\mathrm{PC}_{100}$-value was used to calculate a ratio in $\mathrm{PC}_{100}$ pre/post provocation with saline or allergen. At the allergen provocation day, $\mathrm{P}_{\mathrm{pl}}$ was continuously measured during the whole procedure to assess allergeninduced early and late phase asthmatic responses. Between the measurements of histamine $\mathrm{PC}_{100}$ at $6 \mathrm{~h}$ and $24 \mathrm{~h}$, the animals were removed from the provocation cage and placed in a large cage, where they could move around freely and eat and drink ad libitum. During this transfer, the animals remained connected to the measurement system.

The effect of repeated allergen provocations on the development of BHR was investigated using IgEsensitized guinea-pigs only. One group of animals (IgE-2X) was re-exposed to allergen 7 days after the first provocation. The other group $(\operatorname{IgE}-4 \times)$ was exposed daily for 4 subsequent days, until comparable bronchoconstriction occurred.

In the final group of animals the IgE sensitization procedure was repeated at day 7 and 14 (booster) after the initial sensitization. These animals were exposed to allergen twice a week for 5 weeks, starting at day 28 . In this group airway reactivity to histamine inhalation was assessed at $24 \mathrm{~h}$ before and after the first allergen provocation and (once a week) $24 \mathrm{~h}$ after the $3 \mathrm{rd}$, 5th, 7th, 9th and 10th allergen provocation.

Bronchoalveolar lavage procedure: The bronchoalveolar lavage was performed $24 \mathrm{~h}$ after a single allergen or saline provocation or $24 \mathrm{~h}$ after the last repeated allergen provocation. Animals were anaesthetized with $20 \mathrm{mg} / \mathrm{ml}$ Brietal-sodium, $35 \mathrm{mg} / \mathrm{kg}$ ketamine hydrochloride and $6 \mathrm{mg} / \mathrm{kg}$ Rompun i.p. which ensured a fast, deep anaesthesia. The trachea was exposed and the lungs were gently lavaged via a tracheal cannula with $5 \mathrm{ml}$ of sterile saline at $37^{\circ} \mathrm{C}$, followed by three subsequent aliquots of $8 \mathrm{ml}$ of saline. The recovered lavage samples were cooled on ice, and centrifuged at $200 \times \mathbf{g}$ for $10 \mathrm{~min}$ at $4^{\circ} \mathrm{C}$. The combined pellets were resuspended to a final volume of $1.0 \mathrm{ml}$ in RPMI-1640 medium. Total cell numbers were counted in a Bürker-Türk chamber. For cytological examination, cytospin preparations were made in a Shandon cytospin-2 cytocentrifuge (Shandon Southern Instruments, Swickley, PA, USA) using $100 \mu \mathrm{l}$ aliquots of the cell suspension, spinning at $300 \times \boldsymbol{g}$ for $5 \mathrm{~min}$. The preparations were stained with May-Grünwald and Giemsa. A cell differentiation was performed by counting 400 cells in duplicate.

Chemicals: Histamine hydrochloride, ovalbumin (grade III), and aluminum hydroxide were obtained from Sigma Chemical Co. (St Louis, MO, USA). Freund's Complete Adjuvant was purchased from Difco Laboratories (Detroit, MI, USA), Brietal-sodium (methohexital) from Eli Lilly (Amsterdam, the Netherlands), ketamine hydrochloride from Parke-Davis (Barcelona, Spain), Rompun (2-(2,6-xylidino)-5,6dihydro-4H-1,3-thiazine-hydrochloride, methylparaben) from Bayer (Leverkusen, Germany), and RPMI-1640 medium from Gibco Life Technologies (Paisley, UK).

Data analysis: The magnitude of the EAR after allergen provocation was expressed as the area under the percentage change in $\mathrm{P}_{\mathrm{pl}}$-time curve (AUC) between 0 and $6 \mathrm{~h}$ after provocation, calculated by trapezoid integration over 5 min periods. The magnitude of the LAR was expressed as the AUC between 8 and $24 \mathrm{~h}$ after provocation.

Development of BHR after provocation was evaluated by Student's $t$-test for paired observations. Student's $t$-test for unpaired data was used to compare data from different groups of animals. Differences were considered to be significant when $p<0.05$. All data are presented as means \pm S.E.M.

\section{Results}

Influence of the sensitization regimen: In the first part of this study the development of early and late phase asthmatic reactions, bronchial hyperreactivity and airway inflammation induced by a single allergen provocation was investigated in guinea-pigs sensitized to produce predominantly IgG or IgE antibodies. Allergen-induced asthmatic responses are presented in Table 1. Animals from both sensitization groups responded to allergen provocation with a marked early bronchospasm (IgG, $p<0.01 ; p<0.001$, respectively). In most animals (four of six IgG ani- 
Table 1. Airway responses of guinea-pigs after saline or allergen provocation

\begin{tabular}{|c|c|c|c|}
\hline $\begin{array}{l}\text { Sensitization and } \\
\text { provocation procedure }\end{array}$ & $n$ & $\begin{array}{l}\text { AUC } \\
\text { early reaction } \\
(\% .5 \mathrm{~min})\end{array}$ & $\begin{array}{l}\text { AUC } \\
\text { late reaction } \\
(\% .5 \mathrm{~min})\end{array}$ \\
\hline $\begin{array}{l}\text { Non-sensitized, saline provocation } \\
\text { IgG sensitized, allergen provocation } \\
\text { IgE sensitized, allergen provocation }\end{array}$ & $\begin{array}{l}7 \\
6 \\
9\end{array}$ & $\begin{array}{c}160 \pm 54 \\
4990 \pm 1499^{\star \star} \\
3490 \pm 578^{\star \star \star}\end{array}$ & $\begin{array}{c}873 \pm 412 \\
4373 \pm 1118^{\star \star} \\
6700 \pm 1092^{\star \star \star}\end{array}$ \\
\hline
\end{tabular}

Definition of abbreviations: $A U C=$ Area under $\% \mathrm{P}_{\mathrm{pi}}$-time curve. Data represent mean values \pm S.E.M. Statistical analysis: unpaired Student's $t$-test, compared with saline provocation; ${ }^{\star \star} p<0.01 ;{ }^{\star \star \star} p<0.001$

mals and eight of nine IgE animals), the early reaction was followed by a late asthmatic reaction, which was significantly different from control in both groups(IgG, $p<0.01 ; \operatorname{IgE}, p<0.001$, respectively). No significant differences in the magnitudes of the EAR and LAR were observed between the IgG and IgE animals (Table 1).

The development of BHR to histamine appeared to be equal in both sensitization regimens applied, when compared with control animals (Table 2). At $6 \mathrm{~h}$ after allergen provocation (i.e., between the EAR and LAR), when $\mathrm{P}_{\mathrm{pl}}$ had returned to baseline values, bronchial reactivity was significantly increased in IgG $(p<0.05)$, as well as in IgE sensitized animals $(p<$ 0.01 ). At $24 \mathrm{~h}$ after allergen provocation, i.e., after resolution of the LAR, bronchial reactivity was diminished, but still significantly enhanced for the IgG group $(p<0.05)$, as well as for the IgE animals $(p<$ 0.01) (Table 2).

Examination of the cell content of the bronchoalveolar lavage fluid revealed that the numbers of eosinophils and neutrophils, but not of lymphocytes and macrophages, were significantly and similarly enhanced at $24 \mathrm{~h}$ after allergen provocation, when compared with control, for IgG and IgE sensitized animals (Fig. 1).

Influence of provocation protocol: In animals sensitized to raise IgE antibodies, the development of BHR to histamine at $6 \mathrm{~h}$ as well as at $24 \mathrm{~h}$ after each of repeated allergen provocations was investigated using different challenge protocols (Table 3 ). The development of BHR to histamine inhalation after the first allergen exposure in each protocol corresponded closely to that observed in the single challenged animals. Repetition of the allergen provocation 7 days later (IgE-2x), using the same allergen concentration(s) as before resulted in a comparable development of BHR (Table 3 ). With daily repeated allergen provocations ( $\operatorname{IgE}-4 \mathrm{X}$ ), challenging until respiratory distress was observed, the developed BHR diminished with each subsequent provocation (Table 3), despite a significant increase in allergen provocation concentration from $2.3 \pm 0.4 \mathrm{mg} / \mathrm{ml}$ on the first day to $4.0 \pm 1.1 \mathrm{mg} / \mathrm{ml}$ on the last day $(p<$ 0.05 , paired one-sided Student's $t$-test, $n=6$ ).

The number of eosinophils in the bronchoalveolar lavage fluid when assessed at $24 \mathrm{~h}$ after the last allergen provocation, was significantly increased compared with control animals in both groups (IgE-2×, $p<0.01$; and $\operatorname{IgE}-4 \times, p<0.001)$. The number of neutrophils tended to increase after the second provocation in the $\operatorname{IgE}-2 \times$ group $(p=0.06)$, while only a significant increase was found after the fourth provocation in the $\operatorname{IgE}-4 \times$ group $(p=0.02)$. In these groups the numbers of lymphocytes and macrophages as well as the total number of cells were unchanged compared with control animals (Fig. 2). All cell numbers in the repeated challenge protocols were not significantly different from those observed in single challenged IgE guinea-pigs.

In an attempt to optimize the development of BHR, a final group of IgE sensitized animals was re-sensitized twice and subsequently exposed to allergen twice a week for 5 weeks. The allergen concentration, necessary to obtain an allergic obstruction, increased from $1.0 \pm 0.0 \mathrm{mg} / \mathrm{ml}$ on the first day to 8.7 $\pm 5.7 \mathrm{mg} / \mathrm{ml}$ on the last day (N.S., $n=3$ ). However, a significant increase in bronchial reactivity to inhaled histamine was not observed (Fig. 3). Surprisingly, and in contrast to the former protocols, BHR had not developed at $24 \mathrm{~h}$ after the first provocation. The number of eosinophils, neutrophils and lymphocytes in the bronchoalveolar lavage fluid at $24 \mathrm{~h}$ after the tenth allergen provocation tended to be diminished compared with those observed at $24 \mathrm{~h}$ after a single provocation. Compared with control animals, the numbers of eosinophils $(p<0.001)$ and neutrophils $(p<0.01)$ were still significantly enhanced, however (Fig. 2).

\section{Discussion}

The choice of adjuvant in the sensitization solution determines the distribution of reaginic antibodies produced. Addition of FCA thus resulted in production of almost exclusively (99\%) IgG antibodies, whereas in animals treated with $\mathrm{Al}(\mathrm{OH})_{3} 44 \%$ of the antibodies were of the IgE class. ${ }^{10}$ Despite the apparent relationship between the level of circulating IgE and the severity of the asthmatic symptoms in patients, ${ }^{15}$ a clear difference in the severity of the allergen-induced late asthmatic reaction between IgG and IgE sensitized guinea-pigs was not observed 
Table 2. Bronchial reactivity to histamine in guinea-pigs after saline or allergen provocation.

\begin{tabular}{lccc}
\hline $\begin{array}{l}\text { Sensitization } \\
\text { and provocation }\end{array}$ & $n$ & \multicolumn{2}{c}{$\begin{array}{c}\text { Ratio } \mathrm{PC}_{100} \text { (pre/post-challenge) at different times } \\
\text { after provocation }\end{array}$} \\
\cline { 2 - 4 } & & $6 \mathrm{~h}$ & $24 \mathrm{~h}$ \\
\hline $\begin{array}{l}\text { Non-sensitized, saline provocation } \\
\text { lgG sensitized, allergen provocation }\end{array}$ & 7 & $1.06 \pm 0.08$ & $1.06 \pm 0.09$ \\
lgE sensitized, allergen provocation & 9 & $2.96 \pm 0.69^{\star}$ & $1.69 \pm 0.24^{\star}$ \\
& & $2.93 \pm 0.50^{\star *}$ & $1.56 \pm 0.12^{* *}$ \\
\hline
\end{tabular}

Definition of abbreviations: $\mathrm{PC}_{100}=$ provocation concentration of histamine causing $100 \%$ increase in pleural pressure. Data represent mean values \pm S.E.M. Statistical analysis: unpaired Student's $t-$ test, compared with saline provocation; ${ }^{*} p<0.05 ;{ }^{\star \star} p<0.01$.

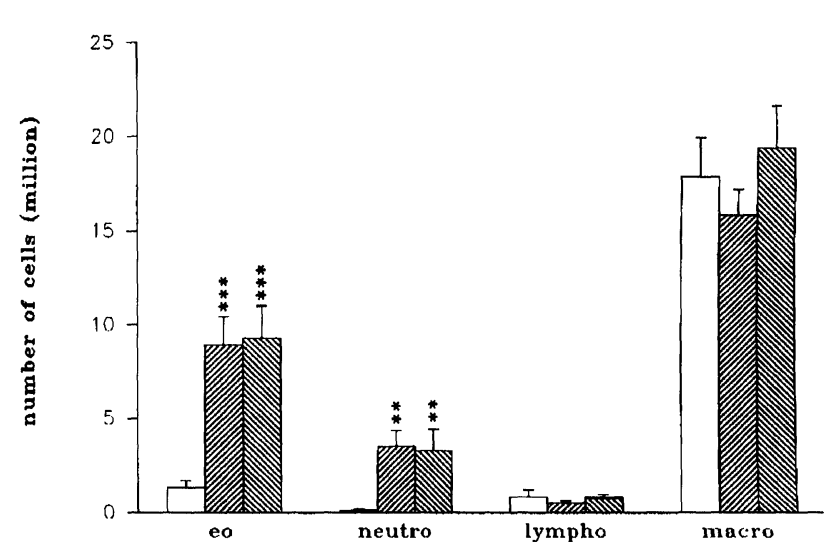

FIG. 1. Cell content of bronchoalveolar lavage fluid, obtained at $24 \mathrm{~h}$ after saline $(\square)$, or allergen provocation of $\lg E(\square)$ or $\lg G(\mathbb{Q})$ sensitized guinea-pigs. Abbreviations: $\mathbf{e o}=\boldsymbol{\theta}$ esinophils, eutro $=$ neutrophils, lympho = lymphocytes, and macro = alveolar macrophages. Data are presented as mean \pm S.E.M. Statistical analysis: unpaired Student's $t$-test, compared with saline challenge, ${ }^{\star \star} p<0.01 ;{ }^{* \star \star} p<0.001$ )

in this study. This is in contrast with the studies performed by Wieslander and colleagues, ${ }^{11}$ who reported that the magnitude of the LAR was determined by the IgE level. On the other hand, Hutson and coworkers ${ }^{16}$ observed a LAR in all guinea-pigs, sensitized to produce IgG antibodies, while Johns et $a l .{ }^{17}$ observed an LAR in only $28 \%$ of the animals using the same sensitization and allergen provocation protocols. In the present study, the development of allergen-induced late asthmatic reactions and BHR to histamine, as well as airway inflammation appeared to be comparable between the IgG and IgE sensitization regimens. Bronchial reactivity to histamine was already increased at $6 \mathrm{~h}$ after allergen provocation, which might have contributed to the magnitude of the LAR. ${ }^{13}$ However, BHR after the LAR was lower than BHR preceding the LAR, indicating that the LAR per se did not substantially contribute to the development of BHR as is currently believed., ${ }^{2,3}$

In the second part of this study attempts were made to increase the development of BHR. Since in asthmatic patients the role of IgE has been well established, ${ }^{15}$ the IgE sensitization procedure was chosen in order to investigate the influence of repeated allergen exposure. Repetition of allergen inhalation 1 week after the first provocation, using identical provocation conditions, did not result in increased BHR, but similar levels were obtained after the EAR as well as after the LAR. This is in agreement with earlier studies by Cockcroft and colleagues ${ }^{18,19}$ who described reproducible EARs and LARs and allergen-induced BHR in 22 asthmatics when the interval between two allergen provocations was longer than 5 days. However, daily repetition of allergen exposure for up to 4 days tended to decrease the development of BHR, despite a small but significant increase in the allergen concentration

Table 3. Bronchial reactivity to histamine in IgE sensitized guinea-pigs after saline or allergen provocation

\begin{tabular}{llcc}
\hline $\begin{array}{l}\text { Provocation } \\
\text { procedure }\end{array}$ & $n$ & \multicolumn{2}{c}{$\begin{array}{c}\text { Ratio } \mathrm{PC}_{\text {100 }} \text { (pre/post-challenge) at different } \\
\text { times after provocation }\end{array}$} \\
\cline { 3 - 4 } & & $6 \mathrm{~h}$ & $24 \mathrm{~h}$ \\
\hline $\begin{array}{l}\text { Saline provocation } \\
\text { Allergen provocation }\end{array}$ & 8 & $1.01 \pm 0.08$ & $0.93 \pm 0.07$ \\
$\begin{array}{l}\text { Repeated allergen provocation } \\
\text { 1st challenge (day 1) }\end{array}$ & 9 & $2.93 \pm 0.50^{\star \star}$ & $1.56 \pm 0.12^{\star \star}$ \\
$\quad$ 2nd challenge (day 8) & 7 & & \\
Repeated allergen provocation & 7 & $2.36 \pm 0.22^{\star \star \star}$ & $2.06 \pm 0.21^{\star \star}$ \\
1st challenge (day 1) & 6 & $2.74 \pm 0.43^{\star \star}$ & $1.56 \pm 0.18^{\star}$ \\
2nd challenge (day 2) & 6 & $4.20 \pm 1.12^{\star}$ & $1.64 \pm 0.30^{\star}$ \\
3rd challenge (day 3) & 6 & $1.96 \pm 0.38^{\star}$ & $1.49 \pm 0.29$ \\
4th challenge (day 4) & 6 & $1.82 \pm 0.35^{\star}$ & $1.40 \pm 0.25$ \\
\hline
\end{tabular}

Definition of abbreviations: $\mathrm{PC}_{100}=$ provocation concentration of histamine causing $100 \%$ increase in pleural pressure. Data represent mean values \pm S.E.M. Statistical analysis: unpaired Student's $t$-test, compared with saline provocation; ${ }^{*} p<0.05 ;{ }^{* \star} p<0.01 ;{ }^{* \star *} p<0.001$. 


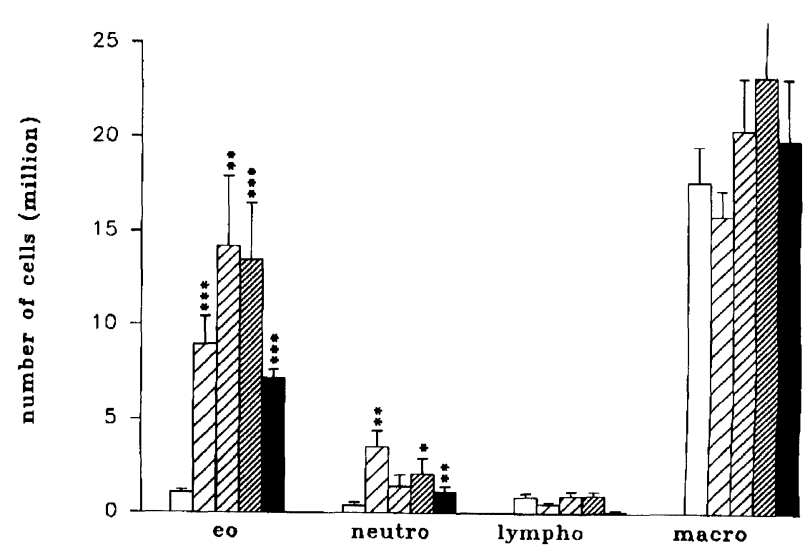

FIG. 2. Cell content of bronchoalveolar lavage fluid, obtained at $24 \mathrm{~h}$ after saline $(\square)$, or the final allergen provocation of IgE sensitized guinea-pigs, exposed once ( $\square, \lg E$ group), twice ( $\square, \lg E-2 \times$ group), four times ( $\lg E-4 \times$ group), or ten times (, $\lg E-10 \times$ group). For protocols see text. Abbreviations: $\quad \mathrm{eo}=$ eosinophils, $\quad$ neutro $=$ neutrophils, $\quad$ lympho $=$ lymphocytes, and macro = alveolar macrophages. Data are presented as mean \pm S.E.M. Statistical analysis: unpaired Student's $t$-test, compared with saline challenge, ${ }^{\star} p<0.05 ;{ }^{\star \star} p<0.01 ;{ }^{\star \star \star} p<0.001$ ).

necessary to obtain an allergen-induced bronchial obstruction.

Since mast cells are involved in the initial processes after allergen provocation, the increasing allergen concentrations may suggest exhaustion of the mast cell population involved when the interval between allergen provocations is short. Indeed, there is evidence that mast cells are not replenished after degranulation. ${ }^{20}$ In a recent study, we have shown that the development of BHR after the EAR as well as the LAR in single allergen-challenged guinea-pigs

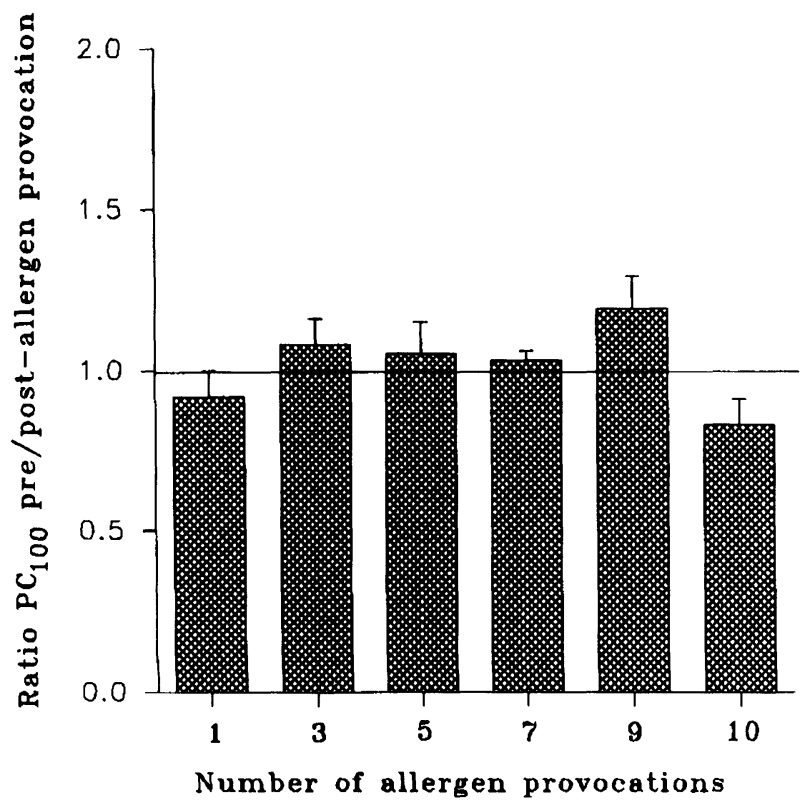

FIG. 3. Bronchial reactivity to inhaled histamine in IgE sensitized guineapigs, boostered twice at day 7 and 14. Allergen exposures were performed twice a week for 5 weeks. Bronchial reactivity was determined once a week, at $24 \mathrm{~h}$ after each odd allergen provocation as well as at $24 \mathrm{~h}$ after the final allergen provocation. Statistical analysis: paired Student's $t$-test compared with prechallenge $\mathrm{PC}_{100}$. No statistically significant differences were observed. is strongly dependent upon the initial degree of airways obstruction during the EAR, ${ }^{13}$ which is predominantly caused by the release of histamine from mast cells. ${ }^{21}$ In addition, we have shown that inhalation of the $\mathrm{H}_{1}$ histamine receptor antagonist mepyramine $(1 \mathrm{mg} / \mathrm{ml}, 10 \mathrm{~min}) 1 \mathrm{~h}$ before allergen provocation prevented the development of both early and late BHR to both histamine and methacholine ${ }^{22}$ indicating that histamine contributes to the development of allergen-induced BHR and that exhaustion of participating mast cells could thus be involved in the diminished development of BHR after repetitive allergen provocations. In a final attempt to increase the severity of allergen-induced BHR IgE sensitized animals were boostered at day 7 and 14 , followed by repetitive allergen provocations twice a week for 5 weeks. Bronchial reactivity was measured every week and did not increase. The failure of booster sensitization to induce BHR after the first allergen provocation was surprising, because using a booster has been claimed to increase BHR, ${ }^{23,24}$ as well as IgE titres and the severity of the LAR. ${ }^{25}$ It is possible that the 14 days between the last sensitization and the first allergen provocation was too short to enable sufficient IgE production. This is, however, unlikely since sensitivity to allergen is correlated with IgE titres, ${ }^{15}$ and each animal in this group responded to the lowest allergen concentration applied.

Investigation of airway inflammation by assessment of inflammatory cell numbers in the bronchoalveolar lavage fluid, revealed that repetitive allergen provocations did not further enhance the numbers of eosinophils and neutrophils, compared with a single allergen provocation, while the number of lymphocytes and macrophages remained unchanged.

There is considerable evidence to support the hypothesis that eosinophils are involved in the pathogenesis of asthma. The release of mediators from activated eosinophils may, for example, cause epithelial damage, ${ }^{26}$ mucosal oedema and reduced mucus clearance, ${ }^{27}$ dysfunction of the autoinhibitory muscarinic $M_{2}$ receptor, ${ }^{28}$ and possibly also a reduced $\beta$-adrenoceptor sensitivity of the airway smooth muscle. ${ }^{29,30}$ In this context, the observation that BHR did not increase after repeated allergen exposure in this model is not surprising, since eosinophilic infiltration also failed to increase. Nevertheless, the (continuous) presence of inflammatory cells in the airways and the reduction or even absence of BHR in the repeated provocation protocols suggest that airway inflammation is not always associated with BHR, as has also been suggested by other studies (for view see Reference 31). A dissociation between the development of inflammatory cell infiltration in the air- 
ways and the absence of BHR after repeated allergen challenge was recently also observed in other studies of ovalbumin sensitized guinea-pigs ${ }^{32}$ and rats. ${ }^{33,34}$ In addition, in mild asthmatics it was recently shown that two repeated allergen provocations within $48 \mathrm{~h}$ did not lead to enhanced early and late obstructive reactions and BHR after the second challenge..$^{35}$

The results from the present and the above-mentioned studies may point to a compensatory mechanism inhibiting the development of increased BHR after repeated allergen exposure by inducing a reduced activation state of the inflammatory cells present in the airways. This could possibly result from a reduced release of histamine as discussed above. In addition, activation of eosinophils and subsequent development of BHR appears to depend on the production of a cytokine profile that is characteristic for $\mathrm{T}$ helper lymphocytes of the $\mathrm{Th}_{2}$ phenotype ${ }^{36}$ The latter cells secrete the interleukins IL-3, IL4 and IL-5 and granulocyte macrophage colony stimulating factor (GM-CSF) and increased mRNA expression of these cytokines has been found in BAL cells and bronchial biopsies from allergic asthmatics. ${ }^{37,38} \mathrm{IL}-5$, together with IL-3 and GM-CSF, enhances infiltration, activation and survival of eosinophils, while IL- 4 promotes the switching of B cell isotypes to production of IgE. On the other hand, proliferation of $\mathrm{Th}_{2}$ cells as well as the B cell isotype switch are inhibited by interferon- $\gamma$ (IFN- $\gamma$ ), which, together with IL-2, is particularly produced by $\mathrm{Th}_{1}$ type lymphocytes. ${ }^{36}$ Recently, it has been demonstrated that immunotherapy by repeated intradermal allergen challenge increased the expression of mRNA for both IFN- $\gamma$ and IL-2 in skin biopsies of patients with hay fever, indicating that a shift to a $\mathrm{Th}_{1}$ cellspecific cytokine profile may be involved in the antigen-induced suppression of the allergic immune response. ${ }^{39}$ This was also indicated by the recent observation in mice that repeated inhalation of ovalbumin causes activation of antigen-specific $\mathrm{CD}^{+}$ $\gamma \delta^{+} \mathrm{T}$ cells, which may suppress $\mathrm{Th}_{2}$ cell-mediated specific IgE production as well $\mathrm{IgG}_{1}$ synthesis and concomitantly enhance $\operatorname{IgG}_{2 \mathrm{a}}$ secretion, presumably by the release of high levels of IFN- $\gamma$ by these cells. ${ }^{40}$

In conclusion, the results described in this paper indicate that an early increase in bronchial reactivity towards inhaled histamine in association with the development of early and late phase asthmatic reactions and airway inflammation can be observed after a single allergen provocation in guinea-pigs, irrespective of whether mainly IgG or IgE antibodies had been raised. The inability to enhance the severity or duration of allergen-induced BHR by increasing the frequency of the sensitization and provocation procedures indicates that additional treatment, for example the use of Bordetella pertussis vaccine as an adjuvant, ${ }^{41}$ is necessary for this purpose.

\section{References}

1. Cockcroft DW, Ruffin RE, Dolovich J, Hargreave FE. Allergen-induced increase in non-allergic bronchial reactivity. Clin Allergy 1977; 7: 503-513.

2. Cartier A, Thomson NC, Frith PA, Roberts R, Hargreave FE. Allergen-induced increase in bronchial responsiveness to histamine: relationship to the late asthmatic response and change in airway caliber. J Allergy Clin Immunol 1982; 70: 170-177.

3. Durham SR, Craddock CF, Cookson WO, Benson MK. Increases in airway responsiveness to histamine precede allergen-induced late asthmatic responses. $J$ Allergy Clin Immunol 1988; 82: 764-770.

4. De Monchy JGR, Kauffman HF, Venge P, et al. Bronchoalveolar eosinophilia during allergen-induced late asthmatic reactions. Am Rev Respir Dis 1985; 131: 373-376.

5. Aalbers R, De Monchy JGR, Kauffman HF, et al. Dynamics of eosinophil infiltration in the bronchial mucosa before and after the late asthmatic reaction. Eur Respir 1993; 6: 840-847.

6. Solley GO, Gleich GJ, Jordon RE, Schroeter AL. The late phase of the immediate wheal and flare skin reaction: its dependence upon IgE antibodies. $J$ Clin Inves 1976; 58: 408-420.

7. Boulet LP, Roberts RS, Dolovich J, Hargreave FE. Prediction of late asthmatic responses to inhaled allergen. Clin Allergy 1984; 14: 379-385.

8. Kirby JG, Robertson DG, Hargreave FE, Dolovich J. Asthmatic responses to inhalation of anti-human IgE. Clin Allergy 1986; 16: 191-194.

9. Andersson P. Antigen-induced bronchial anaphylaxis in actively sensitized guinea pigs. Allergy 1980; 35: 65-71

10. Van Amsterdam RGM, Santing RE, De Boer J, Brouwer F, Zaagsma J. IgG- and IgEmediated histamine release from superfused guinea-pig airway tissues. $J$ Pharm Pharmacol 1991; 10: 694-698.

11. Wieslander $\mathrm{E}$, Andersson $\mathrm{P}$, Linden $\mathrm{M}$, et al. I. Importance of particulate antigen for the induction of dual bronchial reaction in guinea pigs. Agents Actions 1985; 16 $37-38$.

12. Santing RE, Meurs H, van der Mark ThW, et al. A novel method to assess airway function parameters in chronically instrumented, unrestrained guinea pigs. Pulm Pharmacol 1992; 5: 265-272.

13. Santing RE, Olymulder CG, Zaagsma J, Meurs H. Relationships between allergeninduced early and late phase airway obstructions, bronchial hyperreactivity and inflammation in conscious, unrestrained guinea pigs. J Allergy Clin Immunol 1994; 93: 1021-1029.

14. Platt-Mills TAE, Mitchell EB, Nock P, Tovey ER, Moszoro H, Wilkins SR. Reduction of bronchial hyperreactivity during prolonged allergen avoidance. Lancet 1982; ii 675-677.

15. Cockcroft DW, Ruffin RE, Frith PA, et al. Determinants of allergen-induced asthma dose of allergen, circulating IgE antibody concentration, and bronchial responsiveness to inhaled histamine. Am Rev Respir Dis 1979; 120: 1053-1058.

16. Hutson PA, Church MK, Clay TP, Miller P, Holgate ST. Early and late phase bronchoconstriction after allergen challenge of nonanesthetized guinea pigs: the association of disordered airway physiology to leukocyte infiltration. Am Rev Respir Dis 1988; 137: 548-557.

17. Johns K, Sorkness R, Graziano F, Castleman W, Lemanske Jr RF. Contribution of upper airways to antigen-induced late airway obstructive responses in guinea pigs. Am Rev Respir Dis 1990; 142: 138-142.

18. Cockcroft DW, Ruffin RE, Hargreave FE. Effect of SCH 1000 in allergen-induced asthma. Clin Allergy 1978; 8: 361-372.

19. Cockcroft DW, Murdock KY. Comparative effects of inhaled salbutamol, sodium cromoglycate and beclomethasone dipropionate on allergen-induced early asthmatic responses, late asthmatic responses and increased bronchial responsiveness to histamine. J Allergy Clin Immunol 1987; 79: 734-740.

20. Friedman MM, Kalinger MA. Human mast cells and asthma. Am Rev Respir Dis 1987 135: $1157-1164$.

21. Daffonchio L, Payne AN, Lees IW, Whittle BJR, Pharmacological modulation of bronchial anaphylaxis induced by aerosol challenge in anaesthetized guinea pigs. BrJ Pharmacol 1987; 91: 701-708.

22. Santing RE, Schraa EO, Wachters A, Olymulder CG, Zaagsma J, Meurs H. Role of histamine in allergen-induced asthmatic reactions, bronchial hyperreactivity an inflammation in unrestrained guinea pigs. Eur J Pharmacol 1994; 254: 49-57.

23. Iwama T, Shikada K, Yamamoto A, Sakashita M, Hibi M, Tanaka S. Effect of NZ 107 on late-phase airway responses and airway hyperreactivity in guinea pigs. Eur J Pharmacol 1991; 199: 271-278.

24. Shindoh J, Sugiyama S, Takagi K, Satake T, Ozawa T. Recovery time course of airway hyperresponsiveness to acetylcholine after ovalbumin challenge in guinea pigs. Chest 1991; 99: 1274-1279.

25. Andersson P, Brange C, von Kogerer B, Sonmark B, Stahre G. Effect of glucocorticosteroid treatment on ovalbumin-induced IgE-mediated immediate and late allergic response in guinea pig. Int Arch Allergy Appl Immunol 1988; 87: 32-39.

26. Frigas E, Loegering DA, Gleich GJ. Cytotoxic effects of the guinea pig eosinophil major basic protein on tracheal epithelium. Laboratory Invest 1980; 42: 35.

27. James AL, Paré PD, Hogg JC. The mechanics of airway narrowing in asthma. Am Rev Respir Dis 1989; 139: 242-246.

28. Jacoby DB, Gleich GJ, Fryer AD. Human eosinophil major basic protein is an endogenous allosteric antagonist at the inhibitory muscarinic $\mathrm{M}_{2}$ receptor. $J$ Clin Invest 1993; 91: 1314-1318

29. Sneeringer RM, Gleich GJ, Jacoby DB. Eosinophil major basic protein displace ${ }^{125}$-I-iodocyanopindolol from human lung epithelial $\beta$-adrenoceptors. Am Rev Respir Dis 1993; 147: A174.

30. Santing RE, Schraa EO, Vos BG, et al. Dissociation between bronchia hyperreactivity in vivo and reduced $\beta$-adrenoceptor sensitivity in vitro in allergenchallenged guinea pigs. Eur J Pharmacol 1994; 257: 145-152

31. Chapman ID, Foster A, Morley J. The relationship between inflammation and 
hyperreactivity of the airways in asthma. Clin Exp Allergy 1993; 23: 168-171

32. Watson JW, Cohan VL, Shay AK, Freiert KW. Multiple antigen challenge produce pulmonary eosinophilia but not pulmonary hyperresponsiveness in actively sensitized guinea pigs. Agents Actions 1992; 37: 174-177.

33. Kips JC, Cuvelier CA, Pauwels RA. Effect of acute and chronic antigen inhalation on airway morphology and responsiveness in actively sensitized rats. Am Rev Respir Dis 1992; 145: 1306-1310.

34. Haczleu A, Moqbel R, Elwood W, et al. Effects of prolonged repeated exposure to ovalbumin in sensitized brown Norway rats. Am J Respir Crit Care Med 1994; 150: $23-27$.

35. Weller MS, Rijssenbeek LHM, Van de Graaf M, Weller FR, De Monchy JGR. Effect of repeated allergen challenge on early and late asthmatic responses and nonspecific bronchial hyperresponsiveness. Allergy 1993; 48(suppl.): 102.

36. Robinson DS, Durham SR, Kay AB. Cytokines in asthma. Thorax 1993; 48: 845-853.

37. Robinson DS, Hamid Q, Ying S, Tsicopoulos A, et al. Predominant $\mathrm{Th}_{2}$-like bronchoalveolar T-lymphocyte population in atopic asthma. $N$ Engl J Med 1992 326: 298-304.

38. Hamid Q, Azzawi H, Ying S, Moqbel R, et al. Expression of mRNA for interleukin5 in mucosal bronchial biopsies from asthma. J Clin Invest 1991; 87: 1541-1546.
39. Varney VA, Hamid QA, Caga M, et al. Influence of grass pollen immunotherapy on cellular infiltration and cytokine mRNA expression during allergen-induced late phase cutaneous responses. J Clin Invest 1993; 92: 644-651.

40. McMenamin C, Pimm C, McKersey M, Holt PG. Regulation of IgE responses to inhaled antigen in mice by antigen-specific gamma-delta T cells. Science 1994; 265 : 1869-1871.

41. Ishida K, Kelly LJ, Thomson RJ, Beattie LL, Schellenberg RR. Repeated antigen challenge induces airway hyperresponsiveness with tissue eosinophilia in guinea pigs. J Appl Physiol 1989; 67: 1133-1139.

ACKNOWLEDGEMENT: This study was financially supported by the Netherlands Asthma Foundation.

Received 21 November 1994;

accepted in revised form 17 January 1995 


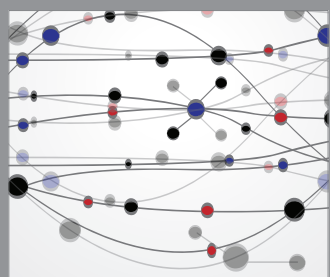

The Scientific World Journal
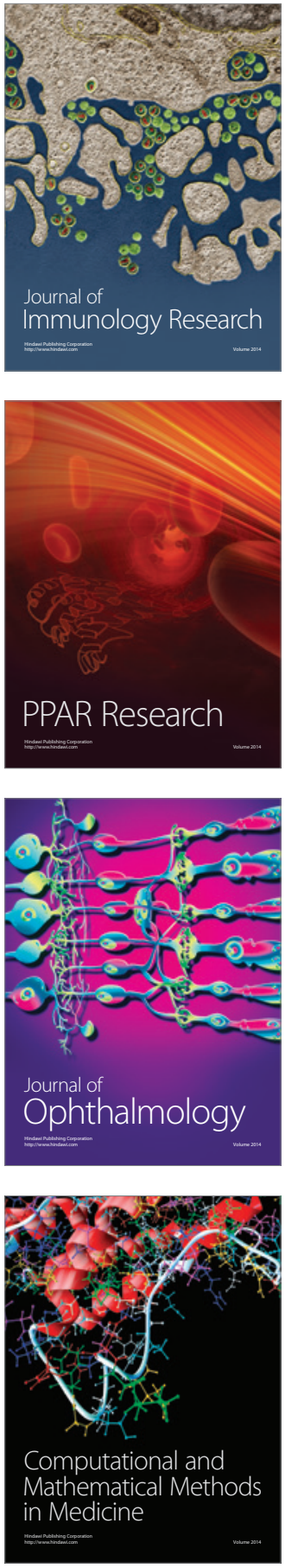

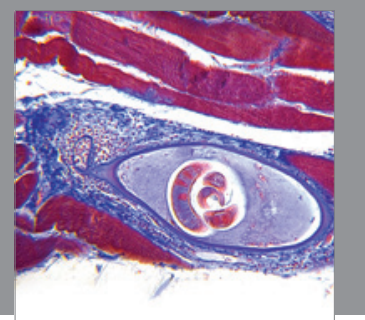

Gastroenterology

Research and Practice
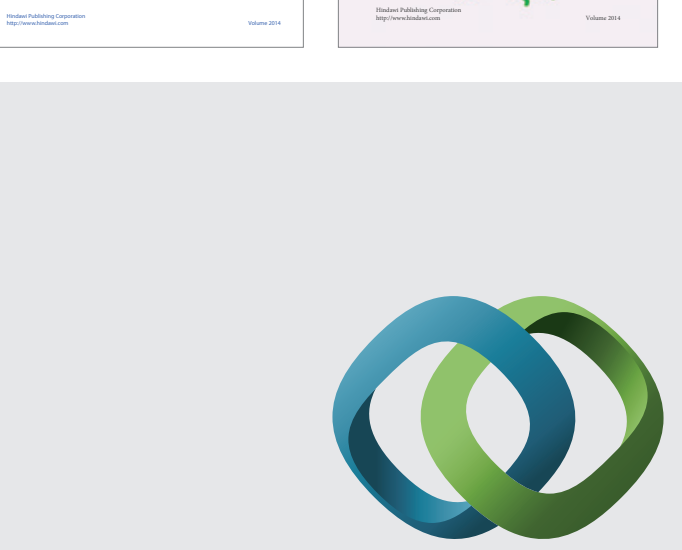

\section{Hindawi}

Submit your manuscripts at

http://www.hindawi.com
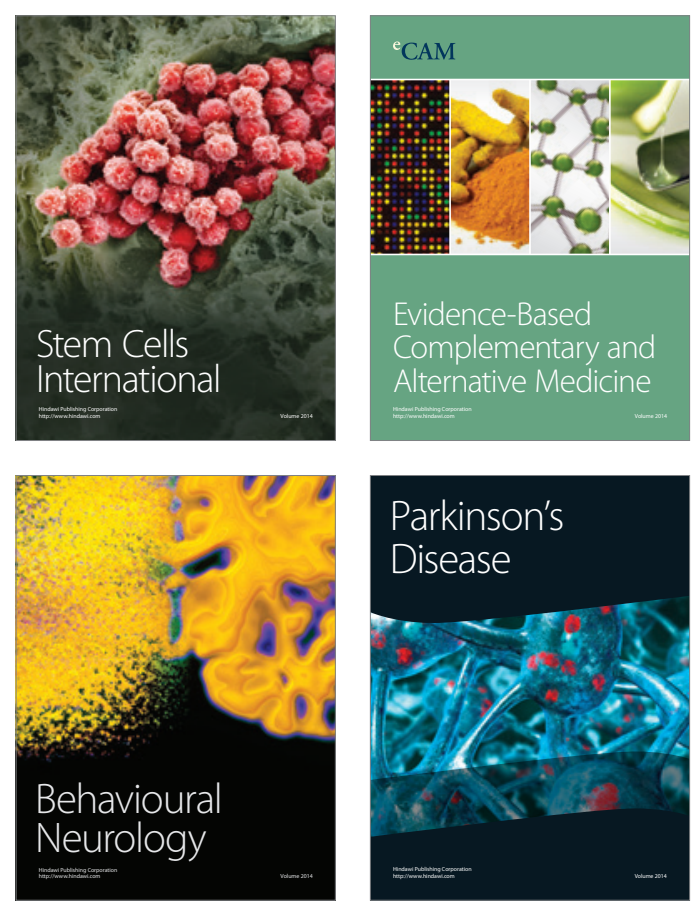

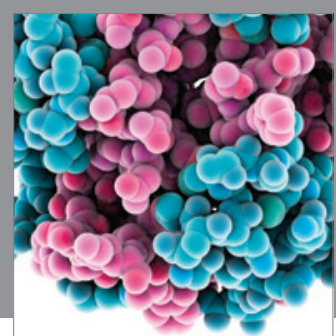

Journal of
Diabetes Research

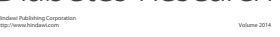

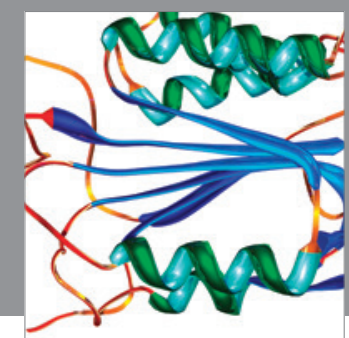

Disease Markers
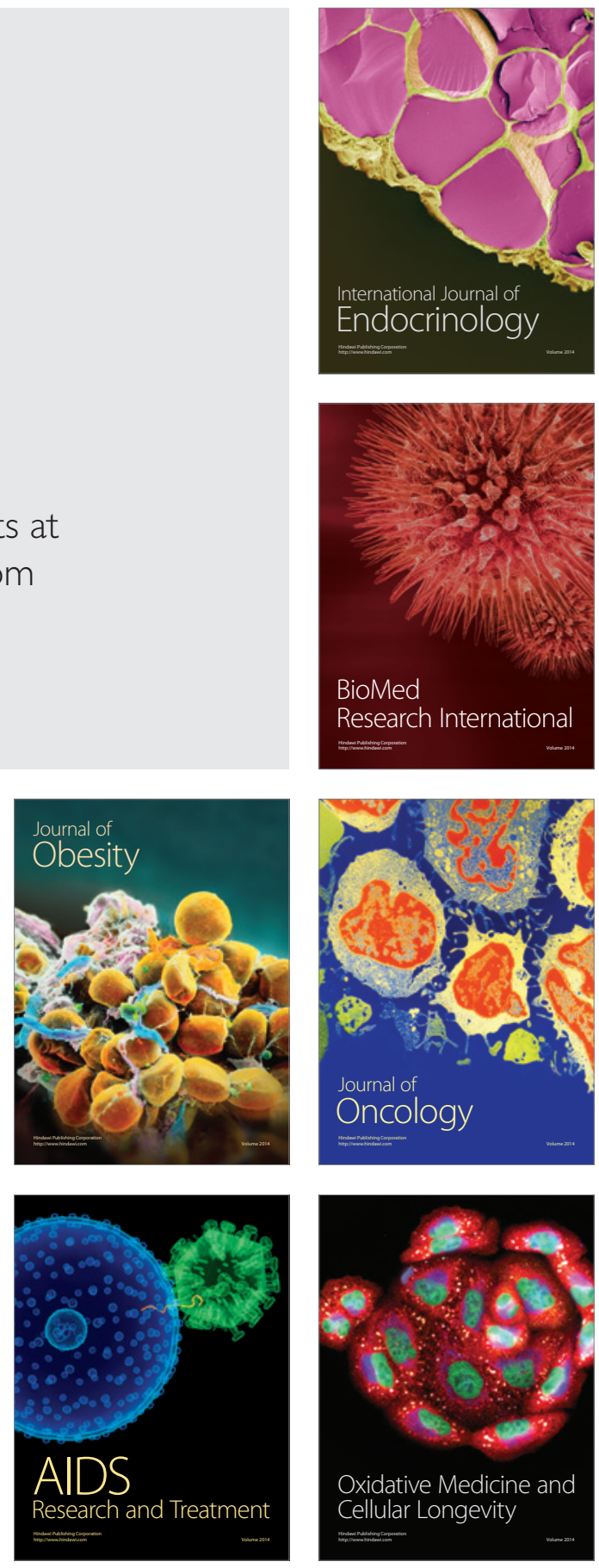